\title{
Public health-relevant consequences of the COVID-19 pandemic on malaria in sub-Saharan Africa: a scoping review
}

\author{
Anna-Katharina Heuschen ${ }^{*}$ (D), Guangyu Lu², Oliver Razum ${ }^{3}$, Alhassan Abdul-Mumin ${ }^{4}$, Osman Sankoh ${ }^{1,5,6}$, \\ Lorenz von Seidlein ${ }^{7}$, Umberto D'Alessandro ${ }^{8}$ and Olaf Müller ${ }^{1}$
}

\begin{abstract}
Background: The COVID-19 pandemic has resulted in unprecedented challenges to health systems worldwide, including the control of non-COVID-19 diseases. Malaria cases and deaths may increase due to the direct and indirect effects of the pandemic in malaria-endemic countries, particularly in sub-Saharan Africa (SSA). This scoping review aims to summarize information on public health-relevant effects of the COVID-19 pandemic on the malaria situation in SSA.
\end{abstract}

Methods: Review of publications and manuscripts on preprint servers, in peer-reviewed journals and in grey literature documents from 1 December, 2019 to 9 June, 2021. A structured search was conducted on different databases using predefined eligibility criteria for the selection of articles.

Results: A total of 51 papers have been included in the analysis. Modelling papers have predicted a significant increase in malaria cases and malaria deaths in SSA due to the effects of the COVID-19 pandemic. Many papers provided potential explanations for expected COVID-19 effects on the malaria burden; these ranged from relevant diagnostical and clinical aspects to reduced access to health care services, impaired availability of curative and preventive commodities and medications, and effects on malaria prevention campaigns. Compared to previous years, fewer country reports provided data on the actual number of malaria cases and deaths in 2020, with mixed results. While highly endemic countries reported evidence of decreased malaria cases in health facilities, low endemic countries reported overall higher numbers of malaria cases and deaths in 2020.

Conclusions: The findings from this review provide evidence for a significant but diverse impact of the COVID-19 pandemic on malaria in SSA. There is the need to further investigate the public health consequences of the COVID-19 pandemic on the malaria burden.

Protocol registered on Open Science Framework: https://doi.org/10.17605/OSF.IO/STQ9D

Keywords: COVID-19, Coronavirus, Malaria, Pandemic, Sub-Saharan Africa, Public health, Global health

*Correspondence: katharina.heuschen@uni-heidelberg.de ${ }^{1}$ Institute of Global Health, Medical School, Ruprecht-Karls-University, Heidelberg, Germany

Full list of author information is available at the end of the article

\section{Background}

The emergence of SARS-CoV-2 in China by the end of 2019 has led to the largest pandemic in recent human history $[1,2]$. By 14 June, 2021, there were some 176 million confirmed cases of COVID-19, including 3.8 million deaths, reported to the World Health Organization (WHO) [3]. The COVID-19 epidemic waves show original author(s) and the source, provide a link to the Creative Commons licence, and indicate if changes were made. The images or other third party material in this article are included in the article's Creative Commons licence, unless indicated otherwise in a credit line to the material. If material is not included in the article's Creative Commons licence and your intended use is not permitted by statutory regulation or exceeds the permitted use, you will need to obtain permission directly from the copyright holder. To view a copy of this licence, visit http://creativecommons.org/licenses/by/4.0/. The Creative Commons Public Domain Dedication waiver (http://creativecommons.org/publicdomain/zero/1.0/) applies to the data made available in this article, unless otherwise stated in a credit line to the data. 
variable dynamics in the different WHO Regions, with the highest burden in the American, European and Southeast Asian Regions [3, 4]. The latter has recently shown particularly high incidence rates, and India is now reporting the second highest number of confirmed cases after the USA [3]. In contrast, the African and the Western Pacific WHO Regions continue to report only relatively low numbers of cases and deaths [3, 4].

It was initially predicted that Africa would be the worst affected region by the COVID-19 pandemic because of its weak health systems, prevailing poverty and the high burden of other infectious diseases $[5,6]$. However, by the end of 2020 about $3.5 \%$ of the global number of COVID19 cases and deaths were reported from this continent, which is home to $17 \%$ of the world's population [3, 7]. Overall, the epidemiology of COVID-19 in Africa remains puzzling [5]. By 14 June, 2021, there were some 3.6 million COVID-19 cases and 89,000 deaths reported from the entire continent, and most of these were from its northern and southern regions $[8,9]$. Potential explanations for such a situation are incomplete data due to much lower testing capacities, a significantly younger population, overall lower population mobility, crossreactive immunity or immunomodulation due to high prevalence of other infectious agents, and effects of public health responses $[5,7,10]$. First findings from SARS$\mathrm{CoV}-2$ seroprevalence surveys support the evidence for significant under-reporting and for a predominance of asymptomatic and mild cases $[11,12]$. Nevertheless, it appears that the second epidemic wave has hit the African continent more severely than the first one, possibly explained by the emergence of more transmissible SARS$\mathrm{CoV}-2$ variants $[7,13]$.

Globally, malaria is still the most important parasitic disease and responsible for a quarter of all deaths among children under 5 years old in sub-Saharan Africa (SSA) $[14,15]$. The efforts for global malaria control and elimination have achieved large successes during the last two decades, but progress has stalled in recent years, and the COVID-19 pandemic could largely reverse the overall trend $[16,17]$. This review aims to summarize currently available data and understanding of the direct and indirect effects of the COVID-19 pandemic on the malaria burden in SSA.

\section{Methods}

\section{Search strategy and selection criteria}

Due to the complex topic and the different type of studies available, a scoping review methodology was chosen [18]. The study protocol (published on OFS, https://doi. org/10.17605/OSF.IO/STQ9D) complies with the 'Preferred Reporting Items for Systematic Reviews and MetaAnalyses for Scoping Reviews (PRISMA-ScR) checklist'
[19]. The following inclusion criteria were applied: papers needed to respect the categories of the PICoframework (Problem: malaria situation; Interest: the public health impact of the COVID-19 pandemic; Context: sub-Saharan Africa) [20]. No restrictions regarding the study type and the publication status were applied. Possible languages were English, French and German; papers published between 1 December, 2019 and 9 June, 2021 were included. In line with the protocol, the search strategy was developed, and the following databases were searched: PubMed; Ovid MEDLINE(R); Web of Science; Biosis Previews; MedRxiv, and The Lancet. Grey literature was included using WHO database and Google Scholar. Three broad blocks of search terms were used: (1) COVID-19; (2) malaria; (3) sub-Saharan Africa. The detailed search strategy is available in Appendix 1.

For the extracted findings, two researchers (OM and $\mathrm{AH}$ ) conducted independently the title screening, then the abstract screening and finally the full text review. The papers selected for full-text reading were assessed for eligibility; ineligible papers did not include information on public health-relevant consequences of the COVID-19 pandemic on malaria in SSA. Inclusion decisions depended on whether the paper agreed to the PICo-framework and the formal eligibility criteria. Results were compared after each step for discussion and for reaching a consensus. For the analysis of the finally included papers, a data extraction table was constructed (Appendix 2).

The following information was extracted from the papers: authors, title, study place, study population, study design, and outcome. Moreover, the papers were categorized by study type: modelling study, report (country report, general report, case report), review, opinion paper, and policy guideline. The information content was structured and analysed around the following themes:

- Modelled impact of COVID-19 on malaria.

- Diagnostical and clinical aspects.

- Access to health care services.

- Availability of curative and preventive malaria commodities.

- Impact on malaria programmes.

- Epidemiologic data from countries.

Based on these findings, a conceptual framework was created, with input from all co-authors (Fig. 1).

\section{Results}

Figure 2 visualizes the study selection process. The initial search produced 851 documents. After removal of 203 duplicates, 648 documents underwent title and abstract screening. After exclusion of 535 documents, which did 
851 documents identified by database search: PubMed (117); Ovid MEDLINE® ALL (90); Web of Science core collection (67); BIOSIS previews (56); medRxiv (234); The Lancet (147); WHO database (3); Google scholar (137)

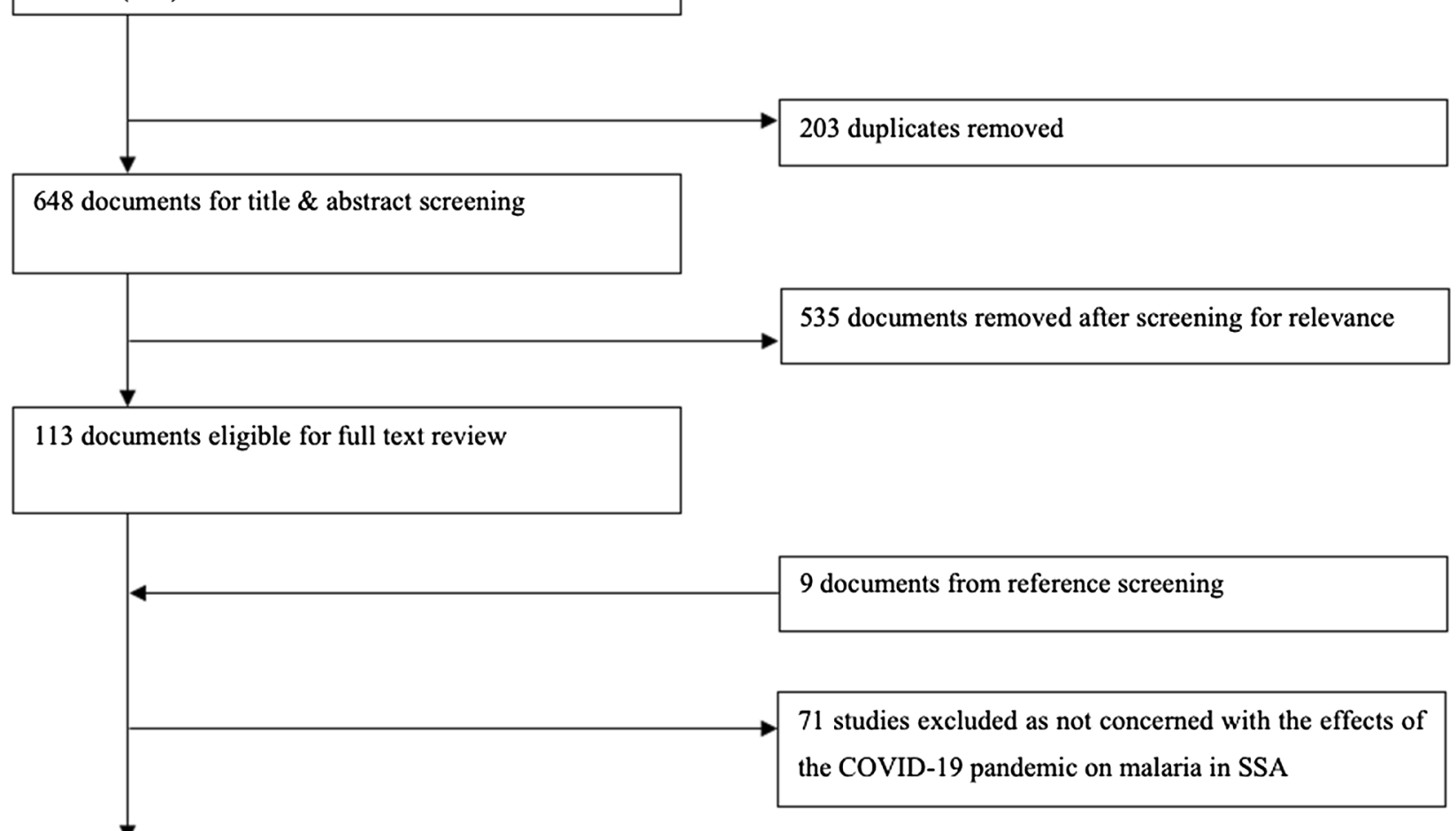

51 documents identified: 6 modelling studies; 17 reports (10 country reports, 6 general reports, 1 case report); 9 reviews; 18 opinion papers; 1 policy guideline

Fig. 1 Conceptual framework presenting the different factors resulting from the global COVID-19 pandemic on the malaria situation in sub-Saharan Africa

not meet the inclusion criteria, 113 papers were included for full text review. Nine papers were added from reference screening; 71 were excluded as they also did not meet the inclusion criteria. Thus, a total of 51 papers were reviewed (6 modelling studies, 10 country reports, 6 general reports, 1 case report, 9 review papers, 18 opinion papers, and 1 policy guideline).

\section{Modelled impact of COVID-19 on malaria}

Five papers predicted the evolution of the malaria burden in SSA based on different potential scenarios. Considering primarily a reduced access to effective anti-malarial treatment and reduced insecticide-treated mosquito net (ITN) distribution, Weiss et al. predicted in their worst-case scenario (75\% fewer anti-malarial drugs and ITNs) and for the year 2020 that in SSA countries, malaria cases would increase by 22\% (from 215 to 262 million) and malaria deaths by $99 \%$ (from 386,000 to $769,000)$; the lower access to anti-malarial treatment had a larger effect than reduced ITN distribution [21]. These estimates mirror those by the WHO, but the authors described the effects of nine different scenarios compared to the effects of three scenarios by Weiss et al. [22]. Comparable estimates were published by Sherrard-Smith et al. for the scenario of complete interruption of ITN distribution and $50 \%$ decreased access to anti-malarials, they predicted malaria deaths would increase in SSA to 779,000 for the year 2020 [23]. A further analysis by 


\begin{tabular}{|c|c|c|c|c|}
\hline $\begin{array}{l}\text { Covid-19 } \\
\text { pandemic } \\
\text { and control } \\
\text { measures } \\
\text { (e .g. lockdown) }\end{array}$ & $\begin{array}{l}\text { Direct and } \\
\text { indirect effects } \\
\text { - Reduced } \\
\text { patient } \\
\text { mobility } \\
\text { - Interruption of } \\
\text { supply chains } \\
\text { - Economic } \\
\text { downturn } \\
\text { - Shortage of } \\
\text { qualified staff } \\
\text { - Suspension of } \\
\text { routine } \\
\text { outpatient } \\
\text { services }\end{array}$ & \begin{tabular}{|l} 
Malaria \\
Surveillance \\
- delayed presentation \\
to health facilities \\
Prevention \\
- Reduced access to \\
preventive services \\
- Low supply of ITN \\
etc. \\
Diagnosis \\
- Lower proportion of \\
confirmed malaria \\
cases \\
Treatment \\
- Reduced access / \\
attendance \\
- Services \\
overburdened \\
- Drug supply \\
/availability reduced
\end{tabular} & $\begin{array}{l}\text { Overall impact } \\
\text { (malaria and } \\
\text { Covid-19) } \\
\text { - Increase in } \\
\text { case numbers } \\
\text { - Increase in } \\
\text { mortality }\end{array}$ & $\begin{array}{l}\text { Increasing } \\
\text { socioeconomic } \\
\text { inequalities }\end{array}$ \\
\hline
\end{tabular}

WHO predicted up to 100,000 additional deaths in 2020 with a $50 \%$ lower access to anti-malarials [17]. However, all these authors emphasized that the projected effects on malaria services and mortality are highly uncertain because these estimates are heavily dependent on how countries respond to the COVID-19 pandemic. Regarding the relative burden of COVID-19 in Africa, one study concluded that the excess disability-adjusted life years (DALYs) lost by malaria due to COVID-19 may exceed those directly lost due to COVID-19 [24].

\section{Diagnostical and clinical aspects}

The clinical manifestations of COVID-19 and malaria largely overlap; fever, headache, joint pain, respiratory symptoms, and general weakness are frequently seen with both diseases [25-27]. Thus, diagnosis based on symptoms alone can result in inadequate treatment, with potentially harmful consequences. Untreated malaria can be rapidly fatal and COVID-19 patients must be quarantined to interrupt community transmission [14, 28]. Despite increasing availability of rapid diagnostic tests (RDTs) for malaria in all endemic areas, presumptive diagnosis of malaria is still common in SSA, and the WHO Malaria Technical Guidelines adapted to COVID19 confirm this situation [29, 30]. Initial information available for 2020 suggests major disruptions in malaria diagnosis and treatment due to COVID-19 [31, 32].

Human travel history is important for SARS-CoV-2 and malaria, as for both of them asymptomatic persons can spread and/or maintain transmission of the infectious agent [26]. Malaria might have been reduced by the COVID-19 movement restrictions, especially in heterogenous malaria-endemic settings where transmission frequently results from migration flows of infected individuals across different regions [33]. Moreover, malaria and SARS-CoV-2 co-infections may be associated with clinical disease modification, although data on this are limited [27, 34-36].

While symptomatic malaria affects mainly children and younger age groups in endemic areas, COVID-19 affects all age groups but is more frequently symptomatic and severe with increasing age [34]. However, in areas of low malaria transmission, the age groups affected by the two diseases largely overlap [37]. RDTs are essential for malaria diagnosis in rural SSA and may also become important for COVID-19, as the PCR test capacity is very limited [32]. However, the impact of rather low sensitivity and specificity of COVID-19 RDTs is still under intense discussion [27, 38]. An additional challenge for differential diagnosis is the increasing frequency of gene-mutated Plasmodium parasites, especially in the Horn of Africa, that escape detection by standard RDTs [37].

The role of anti-malarials, e.g. artemisinin derivates and chloroquine (CQ), in the COVID-19 pandemic is complex. Various artemisinin derivates, artemisinin-based combination therapy (ACT) as well as CQ have been shown to be effective against SARS-CoV-1 and SARSCoV-2 in vitro [39-42]. However, such beneficial effect was not confirmed by several clinical trials [43-46]. The wide use of these treatments in highly malaria-endemic 
countries has been suggested to be responsible for the reported low COVID-19 burden in SSA [36, 47]. On the other hand, the increased usage of these drugs for COVID-19 prevention and treatment in some malariaendemic countries might have reduced malaria [25]. A frequent off-label use of artemisinin-based drugs may also increase the likelihood of emerging drug resistance and thus threatens the most important of the remaining effective anti-malarials [33, 48-50].

\section{Access to health care services}

The COVID-19 pandemic in SSA endangers access to health care services due to several factors. Direct factors include restricted services and closures of health facilities because of reduced health care worker (HCW) capacity due to lack of personal protective equipment (PPE), stigmatization, fear of getting infected, or absence due to COVID-19 quarantine, disease or death [27, 32, 50, 51]. Delayed treatment results in prolonged gametocyte carriage and additional opportunities for transmission.

Moreover, because of overload of COVID-19 patients and consequently reduced time to manage other diseases, or due to movement and travel restrictions and for fear of becoming infected with COVID-19, sick individuals with diseases other than COVID-19 no longer attend health facilities [33, 48, 52]. As older people fear severe COVID19 disease and may thus avoid visiting health facilities, this might affect children the most as they depend on their care givers if sick, including for malaria [35, 49]. Stay-at-home advice for febrile diseases, especially at the beginning of the pandemic, enhanced such behaviour $[17,33]$.

Indirect factors include reduced income during lockdowns due to inability to perform informal work, and subsequently reduced purchasing power [52]. The resulting increase in poverty leads to challenges for paying the costs for routine care, drugs or transportation fees [51]. Lockdowns, movement restrictions and border closures further complicate access to health facilities and have also threatened the functioning of malaria surveillance systems [16, 28, 33, 51]. Institutional mistrust and lack of valid information further reduced visits to health care facilities and reduced uptake of preventive measures; as an example, myths about the spread of COVID-19 via ITNs led to a reduced usage of this essential intervention in Sierra Leone [25].

\section{Availability of curative and preventive commodities and medicines}

Increased material costs, reluctance of producers to invest, travel restrictions, border closures, and lockdowns resulted in a lower availability of medical malaria products $[26,28,48]$. Low- and middle-income countries
(LMICs) are disproportionately affected as they essentially rely on importation of these commodities [52]. Excessive use of anti-malarials for COVID-19 prevention and treatment in some regions has led to shortages for their original purpose $[17,30]$. Some international companies switched from the production of malaria products to COVID-19 products [48, 49, 51]. Difficult access to health facilities lowered the availability of essential drugs and increased their price, with subsequent increases in purchase and usage of sub-standard drugs and alternative medicines [28, 51-53]. In addition, PPE needed for the implementation of different malaria services [e.g., indoor residual spraying of insecticides (IRS)] has become scarce and expensive on global markets $[17,54]$.

\section{Impact of the pandemic on malaria programmes}

The extent of the pandemic's impact on malaria depends on the timing of its waves. The largest effects may occur if the COVID-19 transmission peaks and the planned malaria campaigns overlap [21, 23, 53, 55]. About threequarters of malaria-affected countries reported disruptions of malaria services and programmes [17, 32, 33, $50,53,56-58]$. Re-allocation of funds from other disease control programmes to the control of COVID-19 have been common and pose great problems for malaria control $[30,32,35,59,60]$. Ongoing malaria programmes (e.g., IRS, ITN interventions) need to be adapted to the restrictions associated with COVID-19 control measures, which requires additional financial resources $[32,33,36]$. Programmes for vulnerable populations living in remote areas are particularly at risk as they strongly depend on logistics and external financing [33, 48]. Disrupted ITN programmes will lead to increased malaria transmission as $80 \%$ of the nets are distributed through mass campaigns $[22,48,53,55]$. IRS campaigns face many challenges as they require direct household contact $[33,50$, 57].

Nevertheless, these challenges have led to new approaches: Benin digitalized its ITN mass distribution campaign using a 'no touch' payment for campaign workers. The national strategy was changed from a fixed-point to a door-to-door-distribution procedure, which enabled health workers to provide additional community health education on COVID-19 and other aspects; other countries followed the Benin model and by the end of 2020, $90 \%$ of all globally planned malaria prevention campaigns had been implemented [17, 28, 54, 57, 59].

\section{Epidemiologic data from countries}

Compared to previous years, fewer papers provided data from African countries on the actual number of malaria cases and deaths in 2020. A small study from Sierra Leone reported a significantly lower number of malaria 
outpatient visits in one health facility during the March/ April 2020 lockdown period compared to the same period in 2019 [29]. In addition, preliminary national data from Uganda point to a reduction of malaria cases diagnosed in health facilities during the first quarter of 2020 compared to the same period in 2019 [61]. Another study from Uganda reported a 54\% decrease in visits for malaria treatment of febrile children; visits for antenatal care declined by $26 \%$, restricting the delivery of intermittent preventive malaria treatment in pregnancy (IPTp) [62]. In the Democratic Republic of the Congo (DRC), lower attendance to health facilities for malaria treatment ranged from 20 to $90 \%$, depending on local lockdown measures [63]. In contrast, a study from one rural district in Zimbabwe reported a large increase in malaria cases in 2020 compared to previous years, which was associated with delayed IRS in 2020 [50]. These findings were confirmed by national data from Zimbabwe, which compared the number of malaria cases and deaths in 2020 with those in previous years; in 2020, there was a large excess of reported malaria cases and deaths [27, 64]. Moreover, national data from Zambia showed an increase of malaria cases between August 2019 and June 2020; however, no data from control periods were provided [65].

\section{Discussion}

The COVID-19 pandemic has a massive impact on nearly all countries across the world. While the initial spread of SARS-CoV-2 to Africa has been slow and the COVID-19 burden appears to be much lower than in other continents, the pandemic carries a high potential to negatively affect the control of other diseases, such as malaria [7]. It has already been shown, that the pandemic has resulted in major reductions of incidence of other respiratory diseases due to various effects [66]. Moreover, it has been predicted that the pandemic will result in major disruptions of routine childhood vaccinations, which may cause an increase in vaccine-preventable infectious diseases in SSA [67]. Both malaria and COVID-19 affect disproportionally the low socio-economic classes $[28,32,68]$. It is possible that the COVID-19 pandemic and its indirect effects, including the measures to contain it, may produce collateral damage similar to those seen 6 years ago during the West African Ebola epidemic, i.e., a sharp increase of malaria deaths which finally exceeded the direct Ebola mortality [17, 36, 69]. Thus, understanding how the COVID-19 pandemic affects malaria control measures is of extreme importance for SSA $[17,59]$.

Accelerated malaria control efforts since the early twenty-first century have significantly reduced the malaria burden in Africa and worldwide [17]. Control strategies include ITN and IRS interventions, early diagnosis and rapid treatment with $\mathrm{ACT}$, and intermittent preventive treatment for infants, children and pregnant women [14]. However, the rate of reduction in malaria morbidity and mortality in SSA has recently stalled, and the initial overall positive trend could be seriously reversed due to the effects of the COVID-19 pandemic as shown in several modelling studies [17, 21-23].

In accordance with the conceptual framework, four major themes likely play an important role for the effects of the COVID-19 pandemic on malaria in SSA: (1) diagnostical and clinical aspects; (2) access to health care services; (3) availability of curative and preventive malaria commodities; and, (4) impact on malaria prevention programmes. While diagnostical and clinical aspects will play an obvious role due to the overlapping symptoms of both diseases [27, 70, 71], therapeutic aspects related to initial misperceptions regarding the efficacy of certain anti-malarials against COVID-19 may have been overemphasized $[25,36]$. Co-infection with malaria may complicate COVID-19, while immunomodulation caused by previous malaria exposure may result in less severe COVID-19, as was previously also shown in other respiratory diseases [72-75]. Reduced access to health care services due to direct and indirect effects of the pandemic has a negative impact on access to anti-malarial treatment, thus it would likely have a major effect on the malaria burden in endemic countries [17, 49, 53]. This will be compounded by the clear negative impact of the pandemic on global supply chains for curative and preventive malaria commodities $[48,52]$. The consequences of the pandemic for preventive malaria control programmes have been much emphasized by many of the reviewed papers and particularly in modelling papers. However, as an effect of such early warnings, country programmes and funding for malaria have probably adapted rapidly to the pandemic as early as 2020 , which may have reduced the modelled impact $[28,59]$. International actors such as WHO may have contributed to the prevention of some worst-case scenarios by providing adapted malaria strategies and keeping malaria in their priorities $[17,30]$.

Until June 2021, only a few reports provided actual epidemiological data on malaria in SSA during the first wave of the pandemic in 2020, thus drawing conclusions on these data might be premature. However, these reports showed that the number of reported malaria cases in Sierra Leone, Uganda and the DRC, that are more highly malaria-endemic countries, was much lower than expected [29, 61-63], while the number of reported malaria cases in Zimbabwe and Zambia, that are countries of low endemicity, was higher than in previous years $[27,29,64,65]$. It could be speculated that possibly lower access to health care services in combination with impaired malaria surveillance systems may have 
led to a lower number of reported malaria cases and deaths in these selected highly endemic countries. In the two low-endemic southern SSA countries, disruption of malaria control activities within relatively well-functioning health systems, including surveillance activities, may have resulted in a higher number of reported malaria cases and deaths. More information from other African endemic countries is needed to fully assess such developments $[59,76]$. As the COVID-19 pandemic is far from being under control in most low- and middle-income countries, as new and more infectious SARS-CoV-2 variants are emerging, and as SSA countries have limited access to COVID-19 vaccines, dramatic increases in the malaria burden may occur [59, 77, 78]. Although the findings of existing modelling studies are already alarming, the final impact of the pandemic on the malaria burden could be even more devasting $[21,51]$. Better education, sensitization and de-stigmatization of both diseases is essential, including emphasis on early careseeking behaviour, which also needs more community participation [25, 29]. Community health workers should be encouraged to treat all uncomplicated malaria cases in the community and to refer to health facilities only severe cases [51, 79]. As 2020 was a year with many planned malaria prevention campaigns, the negative effects of disrupted programmes would probably last for some years [21, 23]. Fortunately, the international community, including WHO, acted fast to counteract such developments [17]. However, there is the need for more support for SSA countries from the international community and from high-income countries [32]. Malaria, one of Africa's deadliest diseases, which disproportionally affects the most vulnerable population groups, must be kept under control $[16,35,59]$.

\section{Conclusion}

The findings from this review provide evidence for a significant but diverse impact of the COVID-19 pandemic on the malaria burden in SSA. Only results of further studies will enable a full understanding of these developments and its public health consequences. In the meantime, SSA countries need more support from the international community including the urgent delivery of COVID-19 vaccines for high-risk groups.

\section{Appendix}

Appendix 1: Detailed search strategy

Concept 1 COVID-19

"COVID-19"[ALL] OR "COVID" [ALL] OR "SARSCoV-2"[ALL] OR "coronavirus*"[ALL] OR "2019-

nCoV disease"[ALL] OR "betacoronavirus"[ALL] OR "nCoV"[ALL] OR "COVID-19" [Supplementary Concept] OR "severe acute respiratory syndrome coronavirus 2 " $[\mathrm{nm}]$

Concept 2 malaria

"malaria"”[ALL] OR "paludism"”[ALL] OR

"Malaria"[Mesh] OR "Malaria/prevention and control"[MAJR]

Concept 3 sub-Saharan Africa

"africa" [ALL] OR "sub-saharan"[ALL] OR "SSA"[ALL]

OR "south of the sahara"[ALL] OR "Africa South of the

Sahara"[Mesh]

Concept 1 AND concept 2 AND Concept 3 


\begin{tabular}{|c|c|c|c|c|c|c|}
\hline $\begin{array}{l}\text { Search } \\
\text { number }\end{array}$ & Query & Sort By & Filters & Search details & Results & Time \\
\hline 5 & \#1 AND \#2 AND \#3 & Most recent & $\begin{array}{l}\text { From } 2019 / 12 / 1- \\
2021 / 6 / 9\end{array}$ & $\begin{array}{l}\text { (("COVID-19"[All Fields] OR "covid*"[All } \\
\text { Fields] OR "SARS-CoV-2"[All Fields] } \\
\text { OR "coronavirus*"[All Fields] OR } \\
\text { "2019-nCoV disease"[All Fields] } \\
\text { OR "betacoronavirus"[All Fields] } \\
\text { OR "nCoV"[All Fields] OR "COVID- } \\
\text { 19"[Supplementary Concept] OR } \\
\text { "severe acute respiratory syndrome } \\
\text { coronavirus 2"[Supplementary } \\
\text { Concept]) AND ("malaria*"[All } \\
\text { Fields] OR "paludism*"[All Fields] OR } \\
\text { "Malaria"[MeSH Terms] OR "malaria/ } \\
\text { prevention and control"[MeSH } \\
\text { Major Topic]) AND ("africa"[All Fields] } \\
\text { OR "sub-saharan"[All Fields] OR } \\
\text { "SSA"[All Fields] OR "south of the } \\
\text { sahara"[All Fields] OR "Africa South } \\
\text { of the Sahara"[MeSH Terms])) AND } \\
\text { (2019/12/1:2021/6/9[pdat]) }\end{array}$ & 117 & $13: 34: 11$ \\
\hline 4 & \#1 AND \#2 AND \#3 & Most recent & & $\begin{array}{l}\text { ("COVID-19"[All Fields] OR "covid*"[All } \\
\text { Fields] OR "SARS-CoV-2"[All Fields] } \\
\text { OR "coronavirus""[All Fields] OR } \\
\text { "2019-nCoV disease"[All Fields] } \\
\text { OR "betacoronavirus"[All Fields] } \\
\text { OR "nCoV"[All Fields] OR "COVID- } \\
\text { 19"[Supplementary Concept] OR } \\
\text { "severe acute respiratory syndrome } \\
\text { coronavirus 2"[Supplementary } \\
\text { Concept]) AND ("malaria*"[All } \\
\text { Fields] OR "paludism*"[All Fields] OR } \\
\text { "Malaria"[MeSH Terms] OR "malaria/ } \\
\text { prevention and control"[MeSH Major } \\
\text { Topic]) AND ("africa"[All Fields] OR } \\
\text { "sub-saharan"[All Fields] OR "SSA"[All } \\
\text { Fields] OR "south of the sahara"[All } \\
\text { Fields] OR "Africa South of the } \\
\text { Sahara"[MeSH Terms]) }\end{array}$ & 121 & 13:33:52 \\
\hline 3 & $\begin{array}{l}\text { "africa"[ALL] OR "sub- } \\
\text { saharan"[ALL] OR "SSA"[ALL] } \\
\text { OR "south of the sahara"[ALL] } \\
\text { OR "Africa South of the } \\
\text { Sahara"[Mesh] }\end{array}$ & Most recent & & $\begin{array}{l}\text { "africa"[All Fields] OR "sub-saharan"[All } \\
\text { Fields] OR "SSA"[All Fields] OR "south } \\
\text { of the sahara"[All Fields] OR "Africa } \\
\text { South of the Sahara"[MeSH Terms] }\end{array}$ & 372,746 & $13: 33: 40$ \\
\hline 2 & $\begin{array}{l}\text { "malaria*"[ALL] OR } \\
\text { "paludism*"[ALL] OR } \\
\text { "Malaria"[Mesh] OR "Malaria/ } \\
\text { prevention and control"[MAJR] }\end{array}$ & Most recent & & $\begin{array}{l}\text { "malaria*"[All Fields] OR "paludism*"[All } \\
\text { Fields] OR "Malaria"[MeSH Terms] } \\
\text { OR "malaria/prevention and } \\
\text { control"[MeSH Major Topic] }\end{array}$ & 104,127 & $13: 33: 32$ \\
\hline 1 & $\begin{array}{l}\text { "COVID-19"[ALL] OR } \\
\text { "COVID*"[ALL] OR "SARS-CoV- } \\
\text { 2"[ALL] OR "coronavirus*"[ALL] } \\
\text { OR "2019-nCoV disease"[ALL] } \\
\text { OR "betacoronavirus"[ALL] OR } \\
\text { "nCoV"[ALL] OR "COVID-19" } \\
\text { [Supplementary Concept] OR } \\
\text { "severe acute respiratory syn- } \\
\text { drome coronavirus 2"[nm] }\end{array}$ & Most recent & & $\begin{array}{l}\text { "COVID-19"[All Fields] OR "covid*"[All } \\
\text { Fields] OR "SARS-CoV-2"[All Fields] } \\
\text { OR "coronaviru**"[All Fields] OR } \\
\text { "2019-nCoV disease"[All Fields] } \\
\text { OR "betacoronavirus"[All Fields] } \\
\text { OR "nCoV"[All Fields] OR "COVID- } \\
\text { 19"[Supplementary Concept] OR } \\
\text { "severe acute respiratory syndrome } \\
\text { coronavirus 2"[Supplementary } \\
\text { Concept] }\end{array}$ & 158,835 & $13: 33: 26$ \\
\hline
\end{tabular}




\section{Appendix 2: Data extraction table} Table of included studies.

\begin{tabular}{|c|c|c|c|c|c|}
\hline Authors and year & Title & Study place & Population & Study design & Outcome \\
\hline Aborode et al. [48] & $\begin{array}{l}\text { Fighting COVID-19 at the } \\
\text { expense of malaria in } \\
\text { Africa: The Consequences } \\
\text { and Policy Options }\end{array}$ & Sub-Saharan Africa & General population & Opinion paper & $\begin{array}{l}\text { Supply chain disrup- } \\
\text { tions; financial } \\
\text { shortages; problems } \\
\text { for HCWs; changed } \\
\text { health-seeking } \\
\text { behaviour; simplified } \\
\text { modelling studies, } \\
\text { real outcome could } \\
\text { be worse }\end{array}$ \\
\hline Aïkpon et al. [54] & $\begin{array}{l}\text { Digitalized mass distribu- } \\
\text { tion campaign of ITNs in } \\
\text { the particular context of } \\
\text { Covid-19 pandemic in } \\
\text { Benin: Challenges and } \\
\text { lessons learned }\end{array}$ & Benin & General population & Country report & $\begin{array}{l}\text { Benin: successful ITN } \\
\text { and IRS campaigns, } \\
\text { adapted to COVID-19 } \\
\text { hygiene measures }\end{array}$ \\
\hline Ajayi et al. [28] & $\begin{array}{l}\text { Malaria and COVID-19: } \\
\text { Commonalities, intersec- } \\
\text { tions and implications for } \\
\text { sustaining malaria control }\end{array}$ & Africa & General population & Opinion paper & $\begin{array}{l}\text { COVID-19 and malaria } \\
\text { are both related to } \\
\text { low socio-economic } \\
\text { status; health system } \\
\text { and diagnostical } \\
\text { challenges; changed } \\
\text { health seeking; lack } \\
\text { of reliable data due to } \\
\text { limited reporting }\end{array}$ \\
\hline Amimo et al. [16] & $\begin{array}{l}\text { What does the COVID-19 } \\
\text { pandemic mean for HIV, } \\
\text { tuberculosis and malaria } \\
\text { control? }\end{array}$ & Africa & General population & Report & $\begin{array}{l}\text { Clinical and socio- } \\
\text { economic aspects; } \\
\text { changed health- } \\
\text { seeking behaviour }\end{array}$ \\
\hline Amimo et al. [53] & $\begin{array}{l}\text { The potential impact of } \\
\text { the COVID-19 pandemic } \\
\text { on HIV, tuberculosis and } \\
\text { malaria control in Africa: } \\
\text { A systematic review of } \\
\text { modelling studies and } \\
\text { population surveys }\end{array}$ & Africa & General population & Review & $\begin{array}{l}\text { Malaria programme } \\
\text { and antenatal clinic } \\
\text { disruptions; antenatal } \\
\text { care avoidance; } \\
\text { increased costs for } \\
\text { malaria services }\end{array}$ \\
\hline Anjorin et al. [34] & $\begin{array}{l}\text { Co-morbidities and the } \\
\text { COVID-19 pandemic } \\
\text { dynamics in Africa }\end{array}$ & Sub-Saharan Africa & General population & Review & $\begin{array}{l}\text { Clinical aspects e.g., } \\
\text { overlapping age } \\
\text { groups, common } \\
\text { symptoms; malaria } \\
\text { health service disrup- } \\
\text { tions }\end{array}$ \\
\hline Ansumana et al. [25] & $\begin{array}{l}\text { Effects of disruption from } \\
\text { COVID-19 on anti-malarial } \\
\text { strategies }\end{array}$ & Sub-Saharan Africa & General population & Opinion paper & $\begin{array}{l}\text { Health system chal- } \\
\text { lenges; COVID-19 } \\
\text { myths and misinfor- } \\
\text { mation affect malaria } \\
\text { (reduced ITN usage, } \\
\text { increased anti-malar- } \\
\text { ial uptake) }\end{array}$ \\
\hline $\begin{array}{l}\text { Baral et al. [56]-pre- } \\
\text { print }\end{array}$ & $\begin{array}{l}\text { Competing health risks } \\
\text { associated with the } \\
\text { COVID-19 pandemic } \\
\text { and response: A scoping } \\
\text { review }\end{array}$ & General and Africa & General population & Review & $\begin{array}{l}73 \% \text { disruptions among } \\
\text { malaria programmes; } \\
62 \% \text { decrease of } \\
\text { malaria diagnoses; } \\
\text { delays in malaria } \\
\text { surveillance }\end{array}$ \\
\hline $\begin{array}{l}\text { Bell and Hansen, } \\
\text { [24] - pre-print }\end{array}$ & $\begin{array}{l}\text { Relative burdens of the } \\
\text { COVID-19, malaria, } \\
\text { tuberculosis and HIV/AIDS } \\
\text { epidemics in sub-Saharan } \\
\text { Africa }\end{array}$ & Sub-Saharan Africa & General population & Modelling study & $\begin{array}{l}\text { Low direct COVID-19 } \\
\text { impacts in SSA but } \\
\text { high indirect impacts } \\
\text { on other diseases } \\
\text { such as malaria }\end{array}$ \\
\hline
\end{tabular}




\begin{tabular}{|c|c|c|c|c|c|}
\hline Authors and year & Title & Study place & Population & Study design & Outcome \\
\hline Bell et al. [61] & $\begin{array}{l}\text { Predicting the impact } \\
\text { of COVID-19 and the } \\
\text { potential impact of the } \\
\text { Public Health Response } \\
\text { on Disease Burden in } \\
\text { Uganda }\end{array}$ & Uganda & General population & Modelling study & $\begin{array}{l}\text { Reduction of malaria } \\
\text { cases, admissions, } \\
\text { deaths in Uganda }\end{array}$ \\
\hline Beshir et al. [37] & $\begin{array}{l}\text { Emergence of undetectable } \\
\text { malaria parasites: A threat } \\
\text { under the radar amid the } \\
\text { COVID-19 pandemic? }\end{array}$ & $\begin{array}{l}\text { General and Africa } \\
\text { specific }\end{array}$ & General population & Opinion paper & $\begin{array}{l}\text { Diagnostic challenges } \\
\text { for malaria due to } \\
\text { mutated parasites; } \\
\text { clinical challenges } \\
\text { and treatment } \\
\text { problems }\end{array}$ \\
\hline Brooke et al. [33] & $\begin{array}{l}\text { Implementing malaria } \\
\text { control in South Africa, } \\
\text { Eswatini and southern } \\
\text { Mozambique during the } \\
\text { COVID-19 pandemic }\end{array}$ & $\begin{array}{l}\text { South Africa, Eswatini, } \\
\text { southern Mozam- } \\
\text { bique }\end{array}$ & General population & Review & $\begin{array}{l}\text { Disruptions of malaria } \\
\text { programmes; diag- } \\
\text { nostic, health system } \\
\text { and socio-economic } \\
\text { challenges }\end{array}$ \\
\hline Buonsenso et al. [80] & $\begin{array}{l}\text { Child healthcare and immu- } \\
\text { nizations in sub-Saharan } \\
\text { Africa during the COVID- } \\
19 \text { pandemic }\end{array}$ & Sierra Leone & $\begin{array}{l}\text { Children under the age } \\
\text { of } 5 \text { years }\end{array}$ & Country report & $\begin{array}{l}\text { Reduction in malaria } \\
\text { diagnoses (25-40\%); } \\
\text { no increases in } \\
\text { malaria deaths }\end{array}$ \\
\hline Buonsenso et al. [29] & $\begin{array}{l}\text { Management of malaria in } \\
\text { children under } 5 \text { years } \\
\text { old during COVID-19 } \\
\text { pandemic in Sierra Leone: } \\
\text { A lesson learned? }\end{array}$ & Sierra Leone & Children under 5 years & Country report & $\begin{array}{l}\text { Changes in malaria } \\
\text { diagnoses at health } \\
\text { facilities in context of } \\
\text { the lockdown; com- } \\
\text { munity education } \\
\text { campaign in Sierra } \\
\text { Leone; difficult data } \\
\text { collection }\end{array}$ \\
\hline $\begin{array}{l}\text { Burt et al. [62]—pre- } \\
\text { print }\end{array}$ & $\begin{array}{l}\text { Indirect effects of COVID-19 } \\
\text { on maternal, neonatal, } \\
\text { child, sexual and repro- } \\
\text { ductive health services in } \\
\text { Kampala, Uganda }\end{array}$ & Uganda & Mothers and newborns & Country report & $\begin{array}{l}\text { Greatest impacts } \\
\text { from delayed health } \\
\text { seeking, no public } \\
\text { transport, HCWs } \\
\text { disruptions; closures } \\
\text { of health facilities } \\
\text { for outpatients; } \\
\text { decreased antenatal } \\
\text { care impacts IPTp; } \\
\text { visits for malaria in } \\
\text { children decreased } \\
\text { by } 54 \%\end{array}$ \\
\hline $\begin{array}{l}\text { Chanda-Kapata et al. } \\
\text { [26] }\end{array}$ & $\begin{array}{l}\text { COVID-19 and malaria: A } \\
\text { symptom screening chal- } \\
\text { lenge for malaria-endemic } \\
\text { countries }\end{array}$ & Africa & General population & Opinion paper & $\begin{array}{l}\text { Health system disrup- } \\
\text { tions; clinical aspects; } \\
\text { importance of parallel } \\
\text { testing; malaria } \\
\text { commodities supply } \\
\text { disruptions }\end{array}$ \\
\hline Chasaya [65] & $\begin{array}{l}\text { An update on malaria } \\
\text { trends in Zambia (2019 to } \\
\text { 2020); A descriptive study }\end{array}$ & Zambia & General population & Country report & $\begin{array}{l}\text { Increased malaria test- } \\
\text { ing and cases }\end{array}$ \\
\hline Coker et al. [81] & $\begin{array}{l}\text { Things must not fall apart: } \\
\text { The ripple effects of the } \\
\text { COVID-19 pandemic on } \\
\text { children in sub-Saharan } \\
\text { Africa }\end{array}$ & Sub-Saharan Africa & $\begin{array}{l}\text { Children aged } 0 \text { to } \\
19 \text { years }\end{array}$ & Review & $\begin{array}{l}\text { Malaria elimination } \\
\text { is threatened by } \\
\text { COVID-19 }\end{array}$ \\
\hline Di Gennaro et al. [35] & $\begin{array}{l}\text { Malaria and COVID-19: } \\
\text { Common and different } \\
\text { findings }\end{array}$ & $\begin{array}{l}\text { General and SSA- } \\
\text { specific }\end{array}$ & General population & Opinion paper & $\begin{array}{l}\text { Changed health-seek- } \\
\text { ing behaviour dispro- } \\
\text { portionately affects } \\
\text { children; health } \\
\text { system challenges; } \\
\text { clinical aspects, co- } \\
\text { infections }\end{array}$ \\
\hline
\end{tabular}




\begin{tabular}{|c|c|c|c|c|c|}
\hline Authors and year & Title & Study place & Population & Study design & Outcome \\
\hline $\begin{array}{l}\text { Diongue and Diallo } \\
\text { [82] }\end{array}$ & $\begin{array}{l}\text { COVID-19 during malaria } \\
\text { transmission season in } \\
\text { Africa and why we should } \\
\text { be prepared: An example } \\
\text { from Senegal }\end{array}$ & Senegal & General population & Opinion paper & $\begin{array}{l}\text { Changed health-seek- } \\
\text { ing behaviour; clinical } \\
\text { aspects; COVID-19 } \\
\text { and malaria manage- } \\
\text { ment challenges }\end{array}$ \\
\hline $\begin{array}{l}\text { Elliot Mbunge et al. } \\
\text { [50]—pre-print }\end{array}$ & $\begin{array}{l}\text { Impact of COVID-19 on } \\
\text { malaria elimination: Jux- } \\
\text { taposing indoor residual } \\
\text { spraying and mobile } \\
\text { phones in Buhera Rural } \\
\text { District, Zimbabwe }\end{array}$ & Zimbabwe & General population & Country report & $\begin{array}{l}\text { IRS delays in 2020; } \\
\text { increase in malaria } \\
\text { cases (2981 in } \\
\text { 2020, } 1376 \text { in 2019); } \\
\text { disruptions of health } \\
\text { services; anti-malarial } \\
\text { resistance problems; } \\
\text { challenges for HCWs }\end{array}$ \\
\hline $\begin{array}{l}\text { Emmanuel Awucha } \\
\text { et al. [52] }\end{array}$ & $\begin{array}{l}\text { Impact of the COVID-19 } \\
\text { pandemic on consum- } \\
\text { ers'access to essential } \\
\text { medicines in Nigeria }\end{array}$ & Nigeria & General population & Country report & $\begin{array}{l}\text { Increase in alternative } \\
\text { medicines uptake } \\
(10 \%) \text { and prizes for } \\
\text { anti-malarials; supply } \\
\text { chain disruptions; } \\
74 \% \text { reported less } \\
\text { income during the } \\
\text { pandemic; LMICs } \\
\text { strongly depend on } \\
\text { importations }\end{array}$ \\
\hline Gavi et al. [64] & $\begin{array}{l}\text { Malaria incidence and mor- } \\
\text { tality in Zimbabwe during } \\
\text { the COVID-19 pandemic: } \\
\text { Analysis of routine surveil- } \\
\text { lance data }\end{array}$ & Zimbabwe & General population & Country report & $\begin{array}{l}\text { 16\% more malaria } \\
\text { cases and } 28 \% \text { more } \\
\text { malaria deaths than } \\
\text { expected in } 2020 \text {, } \\
\text { probably follow- } \\
\text { ing several malaria } \\
\text { outbreaks }\end{array}$ \\
\hline Guerra et al. [57] & $\begin{array}{l}\text { Malaria vector control in } \\
\text { sub-Saharan Africa in the } \\
\text { time of COVID-19: No } \\
\text { room for complacency }\end{array}$ & Sub-Saharan Africa & General population & Opinion paper & $\begin{array}{l}\text { Clinical and diagnosti- } \\
\text { cal aspects; impacts } \\
\text { on vector control } \\
\text { measures; malaria } \\
\text { campaign delays }\end{array}$ \\
\hline $\begin{array}{l}\text { Hategeka et al. [63]_- } \\
\text { pre-print }\end{array}$ & $\begin{array}{l}\text { Impact of the COVID-19 } \\
\text { pandemic and response } \\
\text { on the utilization of health } \\
\text { services during the first } \\
\text { wave in Kinshasa, the DRC }\end{array}$ & $\begin{array}{l}\text { Democratic Republic } \\
\text { of the Congo }\end{array}$ & General population & Country report & $\begin{array}{l}\text { 20-90\% reductions in } \\
\text { health facility visits for } \\
\text { malaria, depending } \\
\text { whether the areas } \\
\text { had lockdown or not }\end{array}$ \\
\hline Hussein et al. [36] & $\begin{array}{l}\text { Malaria and COVID-19: } \\
\text { Unmasking their ties }\end{array}$ & $\begin{array}{l}\text { General and Africa } \\
\text { specific }\end{array}$ & General population & Review & $\begin{array}{l}\text { Hypothesis of causal } \\
\text { link between antima- } \\
\text { larials usage and low } \\
\text { COVID-19 incidence; } \\
\text { clinical aspects; chal- } \\
\text { lenges for malaria } \\
\text { programmes }\end{array}$ \\
\hline Inzaule et al. [83] & $\begin{array}{l}\text { Genomic-informed } \\
\text { pathogen surveillance in } \\
\text { Africa: Opportunities and } \\
\text { challenges }\end{array}$ & Africa & General population & Opinion paper & $\begin{array}{l}\text { Benefits for malaria } \\
\text { from genomics-based } \\
\text { surveillance strategy } \\
\text { for COVID-19 }\end{array}$ \\
\hline Kangbai et al. [47] & $\begin{array}{l}\text { Re-reading ACT, BCG, and } \\
\text { low COVID-19 in Africa }\end{array}$ & Africa & General population & Opinion paper & $\begin{array}{l}\text { Hypothesis: low } \\
\text { COVID-19 incidence } \\
\text { due to anti-malarial } \\
\text { usage and malaria } \\
\text { antibodies }\end{array}$ \\
\hline $\begin{array}{l}\text { Kusotera and Nhengu, } \\
\text { [27] }\end{array}$ & $\begin{array}{l}\text { Coronavirus- } 19 \text { and malaria: } \\
\text { The great mimics }\end{array}$ & Zimbabwe & General population & Country report & $\begin{array}{l}\text { Concerns of false } \\
\text { positive SARS-CoV-2 } \\
\text { Ag-RDTs in malaria } \\
\text { infected persons; } \\
\text { increase in malaria } \\
\text { cases in } 2020 \text { (44.7\%); } \\
\text { overlapping clinical } \\
\text { aspects; health sys- } \\
\text { tem challenges }\end{array}$ \\
\hline
\end{tabular}




\begin{tabular}{|c|c|c|c|c|c|}
\hline Authors and year & Title & Study place & Population & Study design & Outcome \\
\hline Makanjuola et al. [84] & $\begin{array}{l}\text { COVID-19 and malaria in } \\
\text { sub-Saharan Africa: Holis- } \\
\text { tic diagnostic approaches } \\
\text { may promote effective } \\
\text { clinical case management }\end{array}$ & Sub-Saharan Africa & General population & Review & $\begin{array}{l}\text { Importance of parallel } \\
\text { testing for SARS- } \\
\text { CoV-2 and malaria; } \\
\text { clinical and health } \\
\text { system difficulties }\end{array}$ \\
\hline $\begin{array}{l}\text { Menelas and Sabin } \\
\text { [71]—pre-print }\end{array}$ & $\begin{array}{l}\text { Malaria or COVID-19? A } \\
\text { case report highlighting } \\
\text { a diagnostic challenge in } \\
\text { Africa }\end{array}$ & Rwanda & 40 years old woman & Case report & $\begin{array}{l}\text { Difficult diagnosis of } \\
\text { malaria-COVID-19 } \\
\text { co-infection }\end{array}$ \\
\hline Mvumbi [85] & $\begin{array}{l}\text { Mass intake of hydroxychlo- } \\
\text { roquine or chloroquine } \\
\text { in the present context of } \\
\text { the Covid-19 outbreak: } \\
\text { Possible consequences in } \\
\text { endemic malaria settings }\end{array}$ & General and Africa & General population & Opinion paper & $\begin{array}{l}\text { Antimalarials uptake } \\
\text { for COVID-19 affect } \\
\text { malaria and resist- } \\
\text { ance development }\end{array}$ \\
\hline Newby et al. [59] & $\begin{array}{l}\text { Global health security } \\
\text { requires endemic disease } \\
\text { eradication }\end{array}$ & General and SSA & General population & Opinion paper & $\begin{array}{l}\text { Over } 90 \% \text { of malaria } \\
\text { campaigns under- } \\
\text { taken in } 2020 ; \\
\text { increase of health } \\
\text { inequities; benefits of } \\
\text { malaria eradication } \\
\text { for COVID-19 }\end{array}$ \\
\hline Nghochuzie et al. [49] & $\begin{array}{l}\text { Pausing the fight against } \\
\text { malaria to combat the } \\
\text { COVID-19 pandemic in } \\
\text { Africa: Is the Future of } \\
\text { Malaria Bleak? }\end{array}$ & sub-Saharan Africa & General population & Opinion paper & $\begin{array}{l}\text { Anti-malarial resist- } \\
\text { ance; RDTs supply } \\
\text { shortages; increases } \\
\text { of malaria cases and } \\
\text { deaths in Zimbabwe } \\
\text { and Cameroon; diag- } \\
\text { nostic challenges; } \\
\text { changed health- } \\
\text { seeking and effects } \\
\text { on children }\end{array}$ \\
\hline $\begin{array}{l}\text { US President's malaria } \\
\text { initiative [86] }\end{array}$ & $\begin{array}{l}15 \text { years of fighting malaria } \\
\text { and saving lives, Annual } \\
\text { Report to Congress, April } \\
2021\end{array}$ & $\begin{array}{l}\text { Sub-Saharan Africa } \\
\text { and Southeast Asia }\end{array}$ & General population & Report & $\begin{array}{l}\text { Seasonal malaria } \\
\text { chemoprevention for } \\
\text { children in Sahel with } \\
\text { minimal delays; com- } \\
\text { munity approach for } \\
\text { malaria prevention; } \\
\text { difficult health care } \\
\text { access (nearly } 50 \% \text { of } \\
\text { the participants) }\end{array}$ \\
\hline Rahi et al. [79] & $\begin{array}{l}\text { COVID-19 Mitigation steps } \\
\text { provide a blueprint for } \\
\text { malaria control and } \\
\text { elimination }\end{array}$ & General and Africa & General population & Opinion paper & $\begin{array}{l}\text { COVID-19 control les- } \\
\text { sons important for } \\
\text { malaria management }\end{array}$ \\
\hline Rogerson et al.[51] & $\begin{array}{l}\text { Identifying and combating } \\
\text { the impacts of COVID-19 } \\
\text { on malaria }\end{array}$ & $\begin{array}{l}\text { General and Africa } \\
\text { specific }\end{array}$ & General population & Opinion paper & $\begin{array}{l}\text { Treatment disruptions; } \\
\text { socio-economic } \\
\text { aspects; challenges } \\
\text { for HCWs; malaria } \\
\text { product disrup- } \\
\text { tions; health system } \\
\text { challenges, malaria } \\
\text { surveillance problems }\end{array}$ \\
\hline Rosenthal et al. [87] & $\begin{array}{l}\text { COVID-19: Shining the light } \\
\text { on Africa }\end{array}$ & Sub-Saharan Africa & General population & Opinion paper & $\begin{array}{l}\text { Financial aspects; anti- } \\
\text { malarial shortages }\end{array}$ \\
\hline $\begin{array}{l}\text { Sherrard-Smith et al. } \\
\text { [23] }\end{array}$ & $\begin{array}{l}\text { The potential public health } \\
\text { consequences of COVID- } \\
19 \text { on malaria in Africa }\end{array}$ & Sub-Saharan Africa & General population & Modelling study & $\begin{array}{l}\text { Malaria deaths in } 2020 \\
\text { could double; impact } \\
\text { of ITN and anti- } \\
\text { malarial disruptions; } \\
\text { benefits of seasonal } \\
\text { malaria chemopre- } \\
\text { vention, mass drug } \\
\text { administration, } \\
\text { presumptive malaria } \\
\text { treatment }\end{array}$ \\
\hline
\end{tabular}




\begin{tabular}{|c|c|c|c|c|c|}
\hline Authors and year & Title & Study place & Population & Study design & Outcome \\
\hline Shi et al. [55] & $\begin{array}{l}\text { Accessing the syndemic } \\
\text { of COVID-19 and malaria } \\
\text { intervention in Africa }\end{array}$ & $\begin{array}{l}\text { Sub-Saharan Africa } \\
\text { (Ethiopia, Nigeria, } \\
\text { Tanzania, Zambia) }\end{array}$ & General population & Modelling study & $\begin{array}{l}\text { Greatest impact on } \\
\text { malaria health } \\
\text { services if COVID-19 } \\
\text { waves and main } \\
\text { malaria season } \\
\text { overlap }\end{array}$ \\
\hline Steketee et al. [31] & $\begin{array}{l}\text { World Malaria Day 2021: } \\
\text { Commemorating } 15 \text { Years } \\
\text { of contribution by the } \\
\text { US President's Malaria } \\
\text { Initiative }\end{array}$ & General and Africa & General population & Opinion paper & $\begin{array}{l}\text { Nearly all malaria cam- } \\
\text { paigns undertaken } \\
\text { despite the pan- } \\
\text { demic; disruptions of } \\
\text { malaria testing, and } \\
\text { treatment; excess } \\
\text { malaria deaths could } \\
\text { exceed COVID-19 } \\
\text { deaths in some } \\
\text { regions }\end{array}$ \\
\hline $\begin{array}{l}\text { The alliance for malaria } \\
\text { prevention [58] }\end{array}$ & 2020 Annual Report & General and Africa & General population & Report & $\begin{array}{l}\text { 74\% of planned ITNs } \\
\text { distributed }\end{array}$ \\
\hline $\begin{array}{l}\text { The Global Fund, } 2021 \\
\text { [32] }\end{array}$ & $\begin{array}{l}\text { The impact of COVID-19 } \\
\text { on HIV, tuberculosis and } \\
\text { malaria services and } \\
\text { systems for health: A } \\
\text { snapshot from } 502 \text { health } \\
\text { facilities across Africa and } \\
\text { Asia }\end{array}$ & Africa and Asia & General population & Report & $\begin{array}{l}\text { Up to } 115 \text { million peo- } \\
\text { ple in extreme pov- } \\
\text { erty; fear of COVID-19 } \\
\text { infection in health } \\
\text { facilities as main } \\
\text { reason for reduced } \\
\text { outpatient visits; } \\
\text { malaria diagnosis and } \\
\text { treatment reduced by } \\
17 \text { and } 15 \% \text {, respec- } \\
\text { tively; anti-malarials } \\
\text { stock-outs ( } 21 \% \text { of all } \\
\text { health facilities), lack } \\
\text { of PPE (64\%), deficits } \\
\text { in COVID-19 testing } \\
\text { capacities, lack of } \\
\text { malaria treatments } \\
\text { (40\%); } \\
\text { about } 75 \% \text { of malaria } \\
\text { programmes } \\
\text { reported disrup- } \\
\text { tions; large financial } \\
\text { resources needed }\end{array}$ \\
\hline Velavan et al. [70] & $\begin{array}{l}\text { COVID-19 and syndemic } \\
\text { challenges in 'Battling } \\
\text { the Big Three': HIV, TB and } \\
\text { malaria }\end{array}$ & General and Africa & General population & Review & $\begin{array}{l}\text { Increased malaria cases } \\
\text { in many countries, } \\
\text { suspended vector } \\
\text { control activities }\end{array}$ \\
\hline Wang et al. [69] & $\begin{array}{l}\text { Preparedness is essential for } \\
\text { malaria-endemic regions } \\
\text { during the COVID-19 } \\
\text { pandemic }\end{array}$ & Africa & General population & Opinion paper & $\begin{array}{l}\text { Measures to reduce } \\
\text { malaria support the } \\
\text { COVID-19 response; } \\
\text { health system chal- } \\
\text { lenges }\end{array}$ \\
\hline Weiss et al. [21] & $\begin{array}{l}\text { Indirect effects of the } \\
\text { COVID-19 pandemic } \\
\text { on malaria intervention } \\
\text { coverage, morbidity, } \\
\text { and mortality in Africa: } \\
\text { A geospatial modelling } \\
\text { analysis }\end{array}$ & Africa & General population & Modelling study & $\begin{array}{l}\text { Anti-malarial disrup- } \\
\text { tions with greater } \\
\text { impact on malaria } \\
\text { incidence and deaths } \\
\text { than ITNs; great } \\
\text { variability between } \\
\text { countries }\end{array}$ \\
\hline WHO [22] & $\begin{array}{l}\text { The potential impact of } \\
\text { health service disruptions } \\
\text { on the burden of malaria: } \\
\text { A modelling analysis for } \\
\text { countries in sub-Saharan } \\
\text { Africa }\end{array}$ & Sub-Saharan Africa & General population & Modelling study & $\begin{array}{l}\text { Importance of ITNs; } \\
\text { impacts on malaria } \\
\text { burden following ITN } \\
\text { and anti-malarials } \\
\text { shortages; worst case } \\
\text { scenario: } 769,000 \\
\text { deaths ( } 743,000 \text { in } \\
\text { SSA), } 70 \% \text { in children } \\
\text { under } 5 \text { years }\end{array}$ \\
\hline
\end{tabular}




\begin{tabular}{|c|c|c|c|c|c|}
\hline Authors and year & Title & Study place & Population & Study design & Outcome \\
\hline$\overline{\mathrm{WHO}[30]}$ & $\begin{array}{l}\text { Tailoring malaria interven- } \\
\text { tions in the COVID-19 } \\
\text { response }\end{array}$ & General and Africa & General population & Policy guideline & $\begin{array}{l}\text { Mass drug administra- } \\
\text { tion or presumptive } \\
\text { treatment of malaria; } \\
\text { adaptation of malaria } \\
\text { interventions }\end{array}$ \\
\hline WHO [17] & $\begin{array}{l}\text { World malaria report } \\
\text { 2020: } 20 \text { years of global } \\
\text { progress and challenges, } \\
\text { Chapter } 10\end{array}$ & $\begin{array}{l}\text { General and SSA } \\
\text { specific }\end{array}$ & General population & $\begin{array}{l}\text { Report and mod- } \\
\text { elling study }\end{array}$ & $\begin{array}{l}\text { Disruptions of malaria } \\
\text { health services; delays } \\
\text { of malaria pro- } \\
\text { grammes; changed } \\
\text { health-seeking; } \\
\text { adaptation of malaria } \\
\text { programmes and } \\
\text { guidelines; malaria } \\
\text { product shortages; } \\
100,000 \text { additional } \\
\text { deaths if } 50 \% \text { anti- } \\
\text { malarials disruptions }\end{array}$ \\
\hline Zawawi et al. [68] & $\begin{array}{l}\text { The impact of COVID-19 } \\
\text { pandemic on malaria } \\
\text { elimination }\end{array}$ & General and Africa & General population & Review & $\begin{array}{l}\text { COVID-19 challenges } \\
\text { Africa's weak health } \\
\text { system; increase } \\
\text { in malaria cases; } \\
\text { indirect social effects, } \\
\text { malaria outbreak in } \\
\text { Zimbabwe during } \\
\text { the lockdown; clinical } \\
\text { challenges }\end{array}$ \\
\hline
\end{tabular}

\section{Abbreviations}

ACT: Artemisinin-based combination therapy; COVID-19: Coronavirus disease 2019; CQ: Chloroquine; DRC: Democratic Republic of the Congo; HCW: Health care worker; IPTp: Intermittent preventive treatment in pregnancy; IRS: Indoor residual spraying of insecticides; ITN: Insecticide-treated mosquito net; LMIC: Low- and middle-income country; PICo: Problem, interest, context; PPE: Personal protective equipment; SARS-CoV-2: Severe acute respiratory coronavirus type 2; SSA: Sub-Saharan Africa; WHO: World Health Organization.

\section{Acknowledgements}

Not applicable.

\section{Authors' contributions}

$\mathrm{AH}$ and $\mathrm{OM}$ performed the systematic search and screening. AH wrote the first draft, GL did the methodological foundation, OR drafted the conceptual framework; all authors reviewed the final manuscript. All authors read and approved the final manuscript.

\section{Funding}

Open Access funding enabled and organized by Projekt DEAL. Anna-Katharina Heuschen acknowledges the support by the Else Kröner-Fresenius-Stiftung within the Heidelberg Graduate School of Global Health (medizinischen fakultät heidelberg, universität heidelberg).

\section{Availability of data and materials}

The datasets used and/or analysed during the current study are available from the corresponding author on reasonable request.

\section{Declarations}

Ethics approval and consent to participate Not applicable.

\section{Consent for publication}

Not applicable.

\section{Competing interests}

The authors declare that they have no competing interests.

\section{Author details}

'Institute of Global Health, Medical School, Ruprecht-Karls-University, Heidelberg, Germany. ${ }^{2}$ Department of Public Health, Medical College, Yangzhou University, Yangzhou, China. ${ }^{3}$ Department of Epidemiology and International Public Health, School of Public Health, Bielefeld University, Bielefeld, Germany. ${ }^{4}$ Department of Paediatrics and Child Health, School of Medicine, University for Development Studies, Tamale, Ghana. ${ }^{5}$ Statistics Sierra Leone, Tower Hill, Freetown, Sierra Leone. ${ }^{6}$ School of Public Health, Faculty of Health Sciences, University of the Witwatersrand, Johannesburg, South Africa. ${ }^{7}$ Mahidol Oxford Tropical Medicine Research Unit, Faculty of Tropical Medicine, Mahidol University, Bangkok, Thailand. ${ }^{8}$ MRC The Gambia, Serekunda, The Gambia.

Received: 15 June 2021 Accepted: 3 Auqust 2021

Published online: 11 August 2021

\section{References}

1. Dawood FS, Ricks P, Njie GJ, Daugherty M, Davis W, Fuller JA, et al. Observations of the global epidemiology of COVID-19 from the prepandemic period using web-based surveillance: a cross-sectional analysis. Lancet Infect Dis. 2020;20:1255-62.

2. Müller O, Lu G, Jahn A, Razum O. COVID-19 control: can Germany learn from China? Int J Health Policy Manag. 2020;9:432-5.

3. WHO Coronavirus (COVID-19) dashboard. World Health Organization. 2021. https://covid19.who.int/table.

4. Lu G, Razum O, Jahn A, Zhang Y, Sutton B, Sridhar D, et al. COVID-19 in Germany and China: mitigation versus elimination strategy. Glob Health Action. 2021;14:1875601.

5. Maeda JM, Nkengasong JN. The puzzle of the COVID-19 pandemic in Africa. Science. 2021;371:27-8. 
6. Massinga Loembé M, Tshangela A, Salyer SJ, Varma JK, Ouma AEO, Nkengasong JN. COVID-19 in Africa: the spread and response. Nat Med. 2020;26:999-1003.

7. Boum Y, Bebell LM, Zoung-Kanyi Bisseck A-C. Africa needs local solutions to face the COVID-19 pandemic. Lancet. 2021;397:1238-40.

8. Salyer SJ, Maeda J, Sembuche S, Kebede Y, Tshangela A, Moussif M, et al. The first and second waves of the COVID-19 pandemic in Africa: a crosssectional study. Lancet. 2021;397:1265-75.

9. WHO. Coronavirus (COVID-19), Africa 2021. https://www.afro.who.int/ health-topics/coronavirus-covid-19.

10. Gutman JR, Lucchi NW, Cantey PT, Steinhardt LC, Samuels AM, Kamb ML, et al. Malaria and parasitic neglected tropical diseases: potential syndemics with COVID-19? Am J Trop Med Hyg. 2020;103:572-7.

11. Mulenga LB, Hines JZ, Fwoloshi S, Chirwa L, Siwingwa M, Yingst $S$, et al. Prevalence of SARS-CoV-2 in six districts in Zambia in July, 2020: a crosssectional cluster sample survey. Lancet Glob Health. 2021;9:e773-81.

12. Usuf E, Roca A. Seroprevalence surveys in sub-Saharan Africa: what do they tell us? Lancet Glob Health. 2021;9:e724-5.

13. Impouma B, Wolfe CM, Mboussou F, Farham B, Saturday T, Pervilhac $C$, et al. Monitoring and evaluation of COVID-19 response in the WHO African Region: challenges and lessons learned. Epidemiol Infect. 2021. https://doi.org/10.1017/S0950268821000807 (Online ahead of print).

14. Müller O. Malaria in Africa: challenges for control and elimination in the 21st century. Frankfurt: Peter Lang Publ; 2011.

15. Global Burden of Disease, Viz Hub. University of Washington. 2021. https://vizhub.healthdata.org/gbd-compare/. Accessed 30 Apr 2021.

16. Amimo F, Lambert B, Magit A. What does the COVID-19 pandemic mean for HIV, tuberculosis, and malaria control? Trop Med Health. 2020;48:32.

17. WHO. World malaria report 2020: 20 years of global progress and challenges. Geneva: World Health Organization; 2020. https://www.who.int/ teams/global-malaria-programme/reports/world-malaria-report-2020.

18. Munn Z, Peters MDJ, Stern C, Tufanaru C, McArthur A, Aromataris E. Systematic review or scoping review? Guidance for authors when choosing between a systematic or scoping review approach. BMC Med Res Methodol. 2018:18:143.

19. Tricco AC, Lillie E, Zarin W, O'Brien KK, Colquhoun H, Levac D, et al. PRISMA extension for scoping reviews (PRISMA-SCR): checklist and explanation. Ann Intern Med. 2018;169:467-73.

20. Schardt C, Adams MB, Owens T, Keitz S, Fontelo P. Utilization of the PICO framework to improve searching PubMed for clinical questions. BMC Med Inform Decis Mak. 2007;7:16.

21. Weiss DJ, Bertozzi-Villa A, Rumisha SF, Amratia P, Arambepola R, Battle KE, et al. Indirect effects of the COVID-19 pandemic on malaria intervention coverage, morbidity, and mortality in Africa: a geospatial modelling analysis. Lancet Infect Dis. 2021;21:59-69.

22. WHO. The potential impact of health service disruptions on the burden of malaria: a modelling analysis for countries in sub-Saharan Africa. Geneva: World Health Organization; 2020.

23. Sherrard-Smith $E$, Hogan AB, Hamlet A, Watson OJ, Whittaker C, Winskill $P$, et al. The potential public health consequences of COVID-19 on malaria in Africa. Nat Med. 2020;26:1411-6.

24. Bell D, Hansen KS. Relative burdens of the COVID-19, malaria, tuberculosis and HIV/AIDS epidemics in sub-Saharan Africa. medRxiv. 2021:2021.03.27.21254483.

25. Ansumana R, Sankoh O, Zumla A. Effects of disruption from COVID-19 on antimalarial strategies. Nat Med. 2020;26:1334-6.

26. Chanda-Kapata P, Kapata N, Zumla A. COVID-19 and malaria: a symptom screening challenge for malaria endemic countries. Int J Infect Dis. 2020:94:151-3.

27. Kusotera T, Nhengu TG. Coronavirus-19 and malaria: the great mimics. Afr J Prim Health Care Fam Med. 2020;12:e1-3

28. Ajayi IO, Ajumobi OO, Falade C. Malaria and COVID-19: commonalities, intersections and implications for sustaining malaria control. Pan Afr Med J. 2020;37(Suppl 1):1.

29. Buonsenso D, lodice F, Cinicola B, Raffaelli F, Sowa S, Ricciardi W. Management of malaria in children under 5-years-old during COVID-19 pandemic in Sierra Leone: a lesson learned? medRxiv. 2020:2020.11.04.20225714.

30. WHO. Tailoring malaria interventions in the COVID-19 response. Global Malaria Programme. Geneva: World Health Organization; 2020. https:// www.who.int/publications/m/item/tailoring-malaria-interventions-inthe-covid-19-response.
31. Steketee RW, Choi M, Linn A, Florey L, Murphy M, Panjabi R. World Malaria Day 2021: commemorating 15 years of contribution by the United States President's Malaria Initiative. Am J Trop Med Hyg. 2021;104:1955-9.

32. The Global Fund. Mitigating the impact of COVID-19 on countries affected by HIV, tuberculosis and malaria. 2020. https://www.theglobalf und.org/media/9819/covid19_mitigatingimpact_report_en.pdf.

33. Brooke B, Raman J, Frean J, Rundle K, Maartens F, Misiani E, et al. Implementing malaria control in South Africa, Eswatini and southern Mozambique during the COVID-19 pandemic. S Afr Med J. 2020;110:1072-6.

34. Anjorin AA, Abioye Al, Asowata OE, Soipe A, Kazeem MI, Adesanya IO, et al. Comorbidities and the COVID-19 pandemic dynamics in Africa. Trop Med Int Health. 2021;26:2-13.

35. Di Gennaro F, Marotta C, Locantore P, Pizzol D, Putoto G. Malaria and COVID-19: common and different findings. Trop Med Infect Dis. 2020;5:141

36. Hussein $\mathrm{MIH}$, Albashir AAD, Elawad OAMA, Homeida A. Malaria and COVID-19: unmasking their ties. Malar J. 2020;19:457.

37. Beshir KB, Grignard L, Hajissa K, Mohammed A, Nurhussein AM, Ishengoma DS, et al. Emergence of undetectable malaria parasites: a threat under the radar amid the COVID-19 pandemic? Am J Trop Med Hyg. 2020;103:558-60.

38. Abdul-Mumin A, Abubakari A, Agbozo F, Abdul-Karim A, Nuertey $B D$, Mumuni K, et al. Field evaluation of specificity and sensitivity of a standard SARS-CoV-2 antigen rapid diagnostic test: a prospective study at a teaching hospital in Northern Ghana. medRxiv. 2021:2021.06.03.21258300.

39. Cao R, Hu H, Li Y, Wang X, Xu M, Liu J, et al. Anti-SARS-CoV-2 potential of artemisinins in vitro. ACS Infect Dis. 2020;6:2524-31.

40. Cortegiani A, Ingoglia G, Ippolito M, Giarratano A, Einav S. A systematic review on the efficacy and safety of chloroquine for the treatment of COVID-19. J Crit Care. 2020:57:279-83.

41. Gendrot M, Duflot I, Boxberger M, Delandre O, Jardot P, Le Bideau M, et al. Antimalarial artemisinin-based combination therapies (ACT) and COVID19 in Africa: in vitro inhibition of SARS-CoV-2 replication by mefloquineartesunate. Int J Infect Dis. 2020:99:437-40.

42. Vincent MJ, Bergeron E, Benjannet S, Erickson BR, Rollin PE, KsiazekTG, et al. Chloroquine is a potent inhibitor of SARS coronavirus infection and spread. Virol J. 2005:2:69.

43. Boulware DR, Pullen MF, Bangdiwala AS, Pastick KA, Lofgren SM, Okafor $\mathrm{EC}$, et al. A randomized trial of hydroxychloroquine as postexposure prophylaxis for Covid-19. N Engl J Med. 2020;383:517-25.

44. Cavalcanti AB, Zampieri FG, Rosa RG, Azevedo LCP, Veiga VC, Avezum A, et al. Hydroxychloroquine with or without azithromycin in mild-tomoderate Covid-19. N Engl J Med. 2020;383:2041-52.

45. Rakedzon S, Neuberger A, Domb AJ, Petersiel N, Schwartz E. From hydroxychloroquine to ivermectin: what are the anti-viral properties of antiparasitic drugs to combat SARS-CoV-2? J Travel Med. 2021;28:taab005.

46. Tang W, Cao Z, Han M, Wang Z, Chen J, Sun W, et al. Hydroxychloroquine in patients with mainly mild to moderate coronavirus disease 2019: open label, randomised controlled trial. BMJ. 2020;369:m1849.

47. Kangbai JB, Sao Babawo L, Kaitibi D, Sandi AA, George AM, Sahr F. Re-reading ACT, BCG, and low COVID-19 in Africa. SN Compr Clin Med. 2021;3:11-5.

48. Aborode AT, David KB, Uwishema O, Nathaniel AL, Imisioluwa JO, Onigbinde SB, et al. Fighting COVID-19 at the expense of malaria in Africa: the consequences and policy options. Am J Trop Med Hyg. 2021;104:26-9.

49. Nghochuzie NN, Olwal CO, Udoakang AJ, Amenga-Etego LN, AmambuaNgwa A. Pausing the fight against malaria to combat the COVID-19 pandemic in Africa: is the future of malaria bleak? Front Microbiol. 2020;11:1476.

50. Mbunge E, Millham R, Sibiya MN, Takavarasha S. Impact of COVID-19 on malaria elimination: juxtaposing indoor residual spraying and mobile phones in Buhera Rural District, Zimbabwe. 2021. https://doi.org/10. 21203/rs.3.rs-173130/v1.

51. Rogerson SJ, Beeson JG, Laman M, Poespoprodjo JR, William T, Simpson JA, et al. Identifying and combating the impacts of COVID-19 on malaria. BMC Med. 2020;18:239.

52. Emmanuel Awucha N, Chinelo Janefrances O, Chima Meshach A, Chiamaka Henrietta J, Ibilolia Daniel A, Esther CN. Impact of the COVID-19 pandemic on consumers' access to essential medicines in Nigeria. Am J Trop Med Hyg. 2020;103:1630-4. 
53. Amimo F, Lambert B, Magit A, Hashizume M. The potential impact of the COVID-19 pandemic on HIV, tuberculosis, and malaria control in Africa: a systematic review of modelling studies and population surveys. 2020. https://doi.org/10.21203/rs.3.rs-103235/v1

54. Aïkpon R, Affoukou C, Hounpkatin B, Eclou DD, Cyaka Y, Egwu E, et al. Digitalized mass distribution campaign of insecticide-treated nets (ITNs) in the particular context of Covid-19 pandemic in Benin: challenges and lessons learned. Malar J. 2020;19:431.

55. Shi B, Zheng J, Xia S, Lin S, Wang X, Liu Y, et al. Accessing the syndemic of COVID-19 and malaria intervention in Africa. Infect Dis Poverty. 2021;10:5.

56. Baral S, Rao A, Twahirwa Rwema JO, Lyons C, Cevik M, Kågesten AE, et al. Competing health risks associated with the COVID-19 pandemic and response: a scoping review. medRxiv. 2021:2021.01.07.21249419.

57. Guerra CA, Tresor Donfack O, Motobe Vaz L, Mba Nlang JA, Nze Nchama LO, Mba Eyono JN, et al. Malaria vector control in sub-Saharan Africa in the time of COVID-19: no room for complacency. BMJ Glob Health. 2020;5:e003880.

58. The Alliance for Malaria Prevention. 2020 annual report. https://alliancefo rmalariaprevention.com/wp-content/uploads/2021/03/FINAL-AMPAnnual-Report-2020.pdf.

59. Newby G, Mpanju-Shumbusho W, Feachem RGA. Global health security requires endemic disease eradication. Lancet. 2021;397:1163-5.

60. RBM Partnership to end malaria. RBM Partnership to End Malaria position on the next Global Fund strategy. 2020. https://endmalaria.org/sites/ default/files/RBM\%20Position\%20Statement\%20on\%20Global\%20Fund\% 27s\%20Strategy.pdf.

61. Bell D, Hansen KS, Kiragga AN, Kambugu A, Kissa J, Mbonye AK. Predicting the impact of COVID-19 and the potential impact of the public health response on disease burden in Uganda. Am J Trop Med Hyg. 2020;103:1191-7.

62. Burt J, Ouma J, Amone A, Aol L, Sekikubo M, Nakimuli A, et al. Indirect effects of COVID-19 on maternal, neonatal, child, sexual and reproductive health services in Kampala, Uganda. medRxiv. 2021:2021.04.23.21255940.

63. Hategeka C, Carter SE, Chenge FM, Katanga EN, Lurton G, Mayaka SM-N, et al. Impact of the COVID-19 pandemic and response on the utilisation of health services during the first wave in Kinshasa, the Democratic Republic of the Congo. medRxiv. 2021:2021.04.08.21255096.

64. Gavi S, Tapera O, Mberikunashe J, Kanyangarara M. Malaria incidence and mortality in Zimbabwe during the COVID-19 pandemic: analysis of routine surveillance data. Malar J. 2021;20:233.

65. Chasaya MPM, Ngomah MA. An update on malaria trends in Zambia (2019 to 2020); a descriptive study. Health Press Zambia Bull. 2020:13-8.

66. Müller O, Razum O, Jahn A. Effects of non-pharmaceutical interventions against COVID-19 on the incidence of other diseases. Lancet Reg Health Eur. 2021;6:100139.

67. Abbas K, Mogasale V. Disruptions to childhood immunisation due to the COVID-19 pandemic. Lancet. 2021. https://doi.org/10.1016/S01406736(21)01418-5 (Online ahead of print).

68. Zawawi A, Alghanmi M, Alsaady I, Gattan H, Zakai H, Couper K. The impact of COVID-19 pandemic on malaria elimination. Parasite Epidemiol Control. 2020;11:e00187.

69. Wang J, Xu C, Wong YK, He Y, Adegnika AA, Kremsner PG, et al. Preparedness is essential for malaria-endemic regions during the COVID-19 pandemic. Lancet. 2020;395:1094-6.

70. Velavan TP, Meyer CG, Esen M, Kremsner PG, Ntoumi F, Consortium P-I-NC. COVID-19 and syndemic challenges in 'Battling the Big Three': HIV, TB and malaria. Int J Infect Dis. 2021;106:29-32.

71. Nkeshimana M, Nsanzimana S. Malaria or COVID-19? A case report highlighting a diagnostic challenge in Africa. 2021. https://doi.org/10.21203/ rs.3.rs-144340/v1
72. Achan J, Wanzira H, Kyagulanyi T, Nuwa A, Magumba G, Kusasira S, et al. Impact of current malaria infection and previous malaria exposure on the clinical profiles and outcome of COVID-19 in a high malaria transmission setting: a prospective cohort study. Lancet. 2021. https://doi.org/10.2139/ ssrn.3844848 (Online ahead of print).

73. Frosch $A E$, John CC. Immunomodulation in Plasmodium falciparum malaria: experiments in nature and their conflicting implications for potential therapeutic agents. Expert Rev Anti Infect Ther. 2012;10:1343-56.

74. Thompson MG, Breiman RF, Hamel MJ, Desai M, Emukule G, Khagayi S, et al. Influenza and malaria coinfection among young children in Western Kenya, 2009-2011. J Infect Dis. 2012;206:1674-84.

75. Edwards CL, Zhang V, Werder RB, Best SE, Sebina I, James KR, et al. Coinfection with blood-stage Plasmodium promotes systemic type i interferon production during pneumovirus infection but impairs inflammation and viral control in the lung. Clin Vaccine Immunol. 2015;22:477-83.

76. Hogan AB, Jewell BL, Sherrard-Smith E, Vesga JF, Watson OJ, Whittaker C, et al. Potential impact of the COVID-19 pandemic on HIV, tuberculosis, and malaria in low-income and middle-income countries: a modelling study. Lancet Glob Health. 2020;8:e1132-41.

77. Figueroa JP, Bottazzi ME, Hotez P, Batista C, Ergonul O, Gilbert S, et al. Urgent needs of low-income and middle-income countries for COVID-19 vaccines and therapeutics. Lancet. 2021;397:562-4.

78. Editorial. The rocky road to universal COVID-19 vaccination. Lancet Infect Dis. 2021;21:743.

79. Rahi M, Das P, Sharma A. COVID-19 Mitigation steps provide a blueprint for malaria control and elimination. Am J Trop Med Hyg. 2020;103:28-30.

80. Buonsenso D, Cinicola B, Kallon MN, lodice F. Child healthcare and immunizations in sub-Saharan Africa during the COVID-19 pandemic. Front Pediatr. 2020;8:517.

81. Coker M, Folayan MO, Michelow IC, Oladokun RE, Torbunde N, Sam-Agudu NA. Things must not fall apart: the ripple effects of the COVID-19 pandemic on children in sub-Saharan Africa. Pediatr Res. 2021;89:1078-86

82. Diongue K, Diallo MA. COVID-19 during malaria transmission season in Africa and why we should be prepared: An example from Senegal. Afr J Lab Med. 2020;9:3.

83. Inzaule SC, Tessema SK, Kebede Y, Ouma AEO, Nkengasong JN. Genomicinformed pathogen surveillance in Africa: opportunities and challenges. Lancet Infect Dis. 2021. https://doi.org/10.1016/S1473-3099(20)30939-7 (Online ahead of print).

84. Makanjuola RO, Ishaleku D, Taylor-Robinson A. COVID-19 and malaria in sub-Saharan Africa: holistic diagnostic approaches may promote effective clinical case management. Microb Infect Dis. 2020;1:100-6.

85. Mvumbi DM. Mass intake of hydroxychloroquine or chloroquine in the present context of the Covid-19 outbreak: possible consequences in endemic malaria settings. Med Hypotheses. 2020;143:109912.

86. P.M.I. US President's malaria initiative. U.S. President's Malaria Initiative Burkina Faso Malaria Operational Plan FY 2020. www.pmi.gov.

87. Rosenthal PJ, Breman JG, Djimde AA, John CC, Kamya MR, Leke RGF, et al. COVID-19: shining the light on Africa. Am J Trop Med Hyg. 2020;102:1145-8.

\section{Publisher's Note}

Springer Nature remains neutral with regard to jurisdictional claims in published maps and institutional affiliations. 